\title{
International Journal of Education Humanities and Social Science
}

ISSN: 2582-0745

Vol. 5, No. 01; 2022

\section{RESEARCH ON THE COGNITION OF PRE-SERVICE HIGH SCHOOL MATHEMATICS TEACHERS FOR IMPLEMENTING INTUITIVE IMAGINATION LITERACY}

\author{
Yanyun Meng \\ Master student, School of Mathematics and Statistics, Shandong Normal University, Jinan, China \\ Xun Zhou \\ Master student, School of Mathematics and Statistics, Shandong Normal University, Jinan, China \\ Zezhong Yang \\ Professor, School of Mathematics and Statistics, Shandong Normal University, Jinan, China
}

https://doi.org/10.54922/IJEHSS.2022.0355

\begin{abstract}
Currently, intuitive imagination literacy has attracted extensive attention from all walks of life. Many relevant problems about it have been studied except the cognition of implementing intuitive imagination literacy of pre-service high school mathematics teachers. To address this gap, this study investigates 51 pre-service high school mathematics teachers through open-ended interviews to learn about the cognitive situation of pre-service high school mathematics teachers for implementing intuitive imagination literacy. After analyzing, it can be found that about implementing intuitive imagination literacy: 1. Pre-service high school mathematics teachers do not have a comprehensive cognition. Their cognition, both as a whole and in different dimensions, does not reach half of the number of implementation recommendations made by the previous authors, and the subjects they realize for implementation are limited to both teachers and students. 2. Pre-service high school mathematics teachers do not have a very reasonable cognition. Some of their ideas lack feasibility or effectiveness and exist a certain one-sidedness, which needs to be further explored and considered. Therefore, it is suggested that: 1. Experts and teachers who are responsible for educating teachers should increase emphasis on intuitive imagination literacy and provide pre-service teachers with more opportunities to practice teaching. 2. Pre-service teachers should take the initiative to study and research, focus on combining theory and practice, and continuously reflect, adjust and improve.
\end{abstract}

Key Words: Pre-service teachers, High school, Mathematics, Intuitive imagination, Literacy, Implementing measures.

\section{INTRODUCTION}

Intuitive imagination is the literacy of using geometric intuition and spatial imagination to perceive the forms and changes of things and using spatial forms, especially graphs, to understand and solve mathematical problems. Intuitive imagination, as one of the six core mathematical literacies, focuses on guiding students to perceive the form and change of things from the perspective of geometric intuition, which is an important part of core literacy. It is also an important means of identifying and posing problems, analyzing and solving them, and a basis for exploring and forming ideas for argumentation, mathematical reasoning, and building abstract structures of thinking (Ministry of Education of the People's Republic of China, 2018). Therefore, it is 


\section{International Journal of Education Humanities and Social Science}

ISSN: 2582-0745

Vol. 5, No. 01; 2022

necessary to develop students' intuitive imagination awareness and intuitive imagination ability in high school mathematics education, and its mathematical education value cannot be underestimated (Zhang and Pei, 2020). However, many scholars and teachers have extensively discussed and studied the present situation of high school students' cognition of intuitive imagination literacy, then they found that the current level of intuitive imagination literacy among high school students is not high (Du, 2019), which showed that intuitive imagination literacy has not been well implemented in actual teaching. What are the reasons for this? How to develop students' intuitive imagination literacy? This is a question worthy of our study.

\section{LITERATURE REVIEW}

Currently, there have been a lot of studies on this issue of implementing intuitive imagination literacy in high school mathematics teaching.

\subsection{The Situation of High School Students' Intuitive Imagination Literacy Level}

In 2018, the General High School Mathematics Curriculum Standards (2017 Edition) (hereinafter referred to as Curriculum Standards (2017 Edition)) specify three levels of intuitive imagination literacy and establish a framework for the corresponding literacy levels. Based on the "pyramidal" assessment framework constructed from the aspects of content, structure, and process, Yin conducted a study on the assessment of high school students' intuitive imagination literacy and found that the level of geometric intuitive imagination was higher than the level of algebraic intuitive imagination (Yin, 2017). Weng found that the overall level of intuitive imagination literacy of high school students is not high, and the overall level is at level 1. Furthermore, the number of students who can reach this level decreases as the level of intuitive imagination literacy increases from level to level (Weng, 2017). Chen found that the overall level of high school students' intuitive imagination literacy was low and students' scores on the three dimensions of spatial imagination, number-shape combination, and geometric intuition were decreasing in order (Chen, 2018). Li further obtained from her study that there are three main deficiencies in the current mathematical intuitive imagination literacy development of high school students: they are unable to make precise identification of mathematical concepts related to intuitive imagination literacy, they are unable to demonstrate solid graphing fundamentals in describing practical problems graphically, and they are unable to solve problems comprehensively with refined mathematical language based on problem characteristics (Li, 2021).

\subsection{The Factors Affecting Students' Intuitive Imagination Literacy}

Yang found that teachers' professionalism had a significant impact on students' visualization ability. In solving conventional visualizable problems, the difficulty of the question, the presentation, and whether students use schematics are factors that affect students' visualization ability (Yang, 2012). Using a self-administered intuitive imagination literacy test paper to measure students, Zheng et al. found that the complexity of the situation and the presentation of the graphs differed in the level of intuitive imagination literacy required of students; there were significant differences in the level of intuitive imagination literacy between boys and girls, and the level of students' intuitive imagination literacy was uneven across geographic regions (Zheng et al., 2020). After analyzing the current situation and differences in intuitive imagination literacy of high school students, Zhang and Pei further pointed out that, on the one hand, the selection of the research subjects and the choice of research methods had an impact on the results, and on the other hand, 


\section{International Journal of Education Humanities and Social Science}

ISSN: 2582-0745

Vol. 5, No. 01; 2022

students' intuitive imagination literacy gradually showed gender differences with age, but the gender differences shown by high school students were not yet stable (Zhang and Pei, 2020). Tao found that all dimensions of logical reasoning ability and all dimensions of intuitive imagination ability showed a positive correlation, while logical reasoning ability and intuitive imagination ability were significantly and positively correlated with academic performance in mathematics (Tao, 2021).

\subsection{Strategies for Cultivating High School Students' Intuitive Imagination Literacy}

Most scholars have focused their attention on this aspect of strategies for developing the intuitive imagination ability of high school students, and their research can be broadly divided into two dimensions: "general teaching" and "classroom teaching".

In the dimension of "general teaching", Yang suggested that the mathematical intuitive teaching should advocate the combination of intuition and speech, including explaining the geometric meaning of abstract mathematical knowledge; constructing the network of verbal and representational representations of mathematical knowledge; and delaying the use of symbolic system (Yang, 2012). Jin suggested that teachers must carefully study the tangents of background materials and the relationship between them and mathematical models in teaching, use them rationally, and guide students to discover mathematical laws and models from them to solve problems (Jin, 2016). From the perspective of PME, Shen and Wang proposed that in the teaching process, teachers should not only pay attention to the mathematical teaching of critical periods, but also provide appropriate prior organizers, stimulate students' metacognitive monitoring and regulation, and design appropriate inquiry-based questions (Shen and Wang, 2017). Li put forward the following requirements for teachers: to carefully study the curriculum standards and clarify the teaching directions and requirements; to broaden the ways, time, and space for teaching intuitive imagination; to strengthen the guidance of intuitive imagination strategies and methods; and to strengthen the practice and perception of students' intuitive imagination ( $\mathrm{Li}, 2019)$. Chang believes that the penetration of intuitive imagination literacy in mathematics teaching has a triple realm: (1) shape - the ability of straightforward sensory imagination; (2) thought - the formation of the idea of combining numbers and shapes; (3) new - the constructing a system of intuitive models (Chang, 2020).

In the dimension of "classroom teaching", Zhang and Han suggested that students should be guided to observe spatial geometry, make models of spatial figures, accumulate representations of spatial figures, and develop their spatial intuitive imagination literacy through hands-on practice and confirmation (Zhang and Han, 2017). Gu and Wang emphasized cultivating the habit of looking at problems and drawing diagrams, learning to graph complex problems, and also learning to use information software to recognize graphical relationships and form spatial concepts $(\mathrm{Gu}$ and Wang, 2020). Liu et al. emphasized the importance of understanding and analyzing problems from a transformational perspective with the help of geometric intuition. They believe that teachers should pay attention to the needs and abilities of students at different levels to develop agile insight into intuition in a gradual manner (Liu et al., 2020). Lin's study on the connection between GeoGebra software and the development of intuitive imagination literacy concluded that it is beneficial for teachers to develop students' intuitive imagination literacy by making reasonable use of software that can demonstrate the generation and dynamic changes of mathematical 


\section{International Journal of Education Humanities and Social Science}

ISSN: 2582-0745

Vol. 5, No. 01; 2022

elements in mathematics teaching (Lin, 2021). Based on his research, Tao suggested strengthening context creation, emphasizing inductive reasoning, and integrating the teaching of logical reasoning and intuitive imagination (Tao, 2021).

\subsection{The Assessment Methods of Intuitive Imagination Literacy of High School Students}

The Curriculum Standards (2017 Edition) emphasize that the evaluation of intuitive imaginative literacy should be based on the curriculum objectives and academic quality standards, pay attention to stage, continuity, and wholeness, and focus on the main performance of the four aspects of intuitive imagination literacy (Ministry of Education of the People's Republic of China, 2018). With reference to Bloom's learning assessment model, PISA learning assessment model, and SOLO learning assessment model, Yu proposed the theoretical concept of classifying mathematical literacy assessment into three forms: knowledge understanding, knowledge transfer, and knowledge innovation ( $\mathrm{Yu}, 2017)$. Zhu constructed a three-dimensional assessment framework of "subject content $\times$ literacy components $\times$ observation indicators" and assigned weight values to the dimensions of mathematical core literacy and observation indicators for high school students to obtain the expressions between mathematical core literacy and the three assessment dimensions of mathematical knowledge, problem-solving, and mathematical thinking (Zhu, 2020). Based on the identification of concepts and theories related to intuitive imagination literacy, Zheng et al. used the Delphi method to construct an intuitive imagination literacy assessment index system consisting of three primary indicators and nine secondary indicators, and then they used a combination of quantitative and qualitative research methods to construct an intuitive imagination literacy assessment model (Zheng et al., 2021).

From the above studies, we can see that many scholars have studied intuitive imagination literacy in terms of its situation, influencing factors, and other aspects, and have especially made a lot of suggestions on the cultivation strategies of intuitive imagination literacy. However, it can be also seen that few people have conducted research on teachers' intuitive imagination literacy, and the research on teachers' cognition of implementing intuitive imagination literacy is in a gap. Through previous studies, it can be found that teachers' cognition of implementing intuitive imagination literacy will affect students' mathematics learning and development to a large extent, so studying this issue is of great practical importance to the implementation of intuitive imagination literacy. Therefore, the purpose of this study is to find out the current pre-service high school mathematics teachers' cognition of implementing intuitive imagination literacy through investigation.

Thus, the main issues of this study are:

1. What areas do the current pre-service high school mathematics teachers focus on regarding the implementation of intuitive imagination literacy?

2. Is the cognition of implementing intuitive imagination literacy comprehensive among current pre-service high school mathematics teachers?

3 . Is the cognition of implementing intuitive imagination literacy reasonable among current preservice high school mathematics teachers?

\section{RESEARCH METHODS}




\section{International Journal of Education Humanities and Social Science}

ISSN: 2582-0745

Vol. 5, No. 01; 2022

\subsection{Participants}

To faithfully reflect the pre-service high school mathematics teachers' cognition for implementing intuitive imagination literacy, this study used the whole-group sampling method and selected 51 masters of education majoring in mathematics of grade 2021 from the School of Mathematics and Statistics of Shandong Normal University as the survey sample. They include 48 girls and 3 boys, whose ages are distributed between 21 and 26 years old. All of them hold high school mathematics teacher qualification certificates and have the intention to go to high school for employment in the future.

\subsection{Instrument}

In this study, we conducted open-ended interviews with an interview outline containing a total of 10 questions, of which the two most prominent questions were, "How do you think intuitive imagination literacy can be implemented in high school?" and "How do you think intuitive imagination literacy can be implemented in mathematics classrooms?" The open-ended interview method is adopted because it is fast, convenient, flexible, not restricted by written language, and facilitates in-depth investigations to obtain the most direct information. The reason for choosing the above questions is to find out the pre-service high school mathematics teachers' real cognitive situation for implementing intuitive imagination literacy.

\subsection{Data Collection}

To ensure the reliability of the research, the open-ended interview method was used to interview 51 masters of education one by one individually, and the interview content was recorded during the whole process after the consent of the other party was sought.

\subsection{Data Processing}

Firstly, we converted the interview recording content into text form, removed um, ah, and other discourse markers, strictly followed the original words of the interview to sort out. The core ideas they expressed were further extracted and categorized into two primary indicators: "general teaching" and "classroom teaching", and according to the subject of implementation, each primary indicator was divided into two secondary indicators: "teachers" and "students", which were represented by A, B, C, and D respectively. Then we used SPSS to count the number of people mentioned in each of the above items and calculate the corresponding percentages. Finally, the corresponding tables were made based on the data obtained.

\section{RESULTS}

\subsection{Cognitive Focus}

The core ideas expressed by pre-service high school mathematics teachers were extracted and summarized into a total of 37 points.

For the dimension of "general teaching", there are 17 items, 10 of which are implemented by teachers and 7 by students. The cognition of pre-service teachers is mainly focused on the fact of "improve the ability to combine numbers and shapes", which was recognized by 19 people, accounting for $37.25 \%$ of the total number of them; followed by this is "free use of spatial imagination", which was recognized by 12 people, accounting for $23.53 \%$ of the total; next is "hands-on, experience, explore", which was recognized by 11 people, accounting for $21.57 \%$ of the total. All of these elements were implemented by students. Thus, for the "general teaching" 


\section{International Journal of Education Humanities and Social Science}

ISSN: 2582-0745

Vol. 5, No. 01; 2022

dimension, pre-service teachers recognize the importance of students and teachers in implementing intuitive imagination literacy, and they pay more attention to the important role of students as learning agents in this dimension. They realized that to better implement intuitive imagination literacy, students need to have the ability to combine numbers and shapes, spatial imagination, and hands-on practice. Meanwhile, teachers need to have the awareness of developing students' intuitive imagination and have certain teaching skills.

For the dimension of "classroom teaching", there are 20 items, 11 of which are implemented by teachers and 9 by students. The cognition of pre-service teachers is mainly focused on the fact of "Use visual tools such as graphics", which was recognized by 31 people, accounting for $60.78 \%$ of the total number of them; next is "Demonstrate with the help of modern information technology such as multimedia", which was recognized by 29 people, accounting for $56.86 \%$ of the total. All of these elements were implemented by teachers. Thus, for the "classroom teaching" dimension, the pre-service teachers were also able to recognize the importance of students and teachers in implementing intuitive imagination literacy, and pay more attention to the important role of teachers in classroom teaching. They realize that teachers need to relate to real-life situations in the classroom teaching process and teach with the help of modern information technology and visual tools to stimulate students' interest in learning, and they also emphasize students' direct participation in the learning process. The details are shown in Table 1.

Table 1. Statistics of cognitive focus

\begin{tabular}{lllll}
\hline Primary & Seconda & & & Num \\
Indicato & ry & Cod & Percen \\
rs & Indicato & e & Content & ber tage
\end{tabular}

\begin{tabular}{|c|c|c|c|c|c|}
\hline \multirow{8}{*}{$\begin{array}{l}\text { General } \\
\text { Teachin } \\
\text { g }\end{array}$} & \multirow{8}{*}{$\begin{array}{l}\text { A } \\
\text { Teacher } \\
\text { s }\end{array}$} & A1 & Establish a clear teaching program & 5 & 9.80 \\
\hline & & A2 & Provide reinforcement to students & 2 & 3.92 \\
\hline & & A3 & Enhance the focus on core literacy & 3 & 5.88 \\
\hline & & A4 & $\begin{array}{l}\text { Construct a suitable evaluation } \\
\text { system }\end{array}$ & 1 & 1.96 \\
\hline & & A5 & Cultivate students in a subtle way & 1 & 1.96 \\
\hline & & A6 & Possess some teaching skills & 2 & 3.92 \\
\hline & & A7 & Make knowledge visual & 8 & 15.69 \\
\hline & & A8 & $\begin{array}{l}\text { Have the awareness of developing } \\
\text { students intuitive imagination } \\
\text { literacy }\end{array}$ & 5 & 9.80 \\
\hline
\end{tabular}




\section{International Journal of Education Humanities and Social Science}

ISSN: 2582-0745

Vol. 5, No. 01; 2022

\begin{tabular}{|c|c|c|c|c|c|}
\hline & & A9 & $\begin{array}{l}\text { Cultivate students' innovative } \\
\text { thinking }\end{array}$ & 1 & 1.96 \\
\hline & & A10 & $\begin{array}{l}\text { Give students the opportunity to } \\
\text { solve problems independently on } \\
\text { their own }\end{array}$ & 1 & 1.96 \\
\hline & & B1 & Learn to paint & 1 & 1.96 \\
\hline & & B2 & Connect with real life & 3 & 5.88 \\
\hline & & B3 & Hands-on, experience, explore & 11 & 21.57 \\
\hline & B & B4 & Free use of spatial imagination & 12 & 23.53 \\
\hline & Students & B5 & Develop geometric spatial ability & 7 & 13.73 \\
\hline & & B6 & $\begin{array}{l}\text { Improve the ability to combine } \\
\text { numbers and shapes }\end{array}$ & 19 & 37.25 \\
\hline & & B7 & Enhance the focus on core literacy & 1 & 1.96 \\
\hline & & $\mathrm{C} 1$ & $\begin{array}{l}\text { Demonstrate with the help of modern } \\
\text { information technology such as } \\
\text { multimedia }\end{array}$ & 29 & 56.86 \\
\hline & & $\mathrm{C} 2$ & Use visual tools such as graphics & 31 & 60.78 \\
\hline & & $\mathrm{C} 3$ & Combine with life examples & 10 & 19.61 \\
\hline & & $\mathrm{C} 4$ & $\begin{array}{l}\text { Stimulate students' interest in } \\
\text { learning }\end{array}$ & 6 & 11.76 \\
\hline Classro & $\begin{array}{l}\text { C } \\
\text { Teacher }\end{array}$ & $\mathrm{C} 5$ & $\begin{array}{l}\text { Create appropriate teaching } \\
\text { situations }\end{array}$ & 4 & 7.84 \\
\hline g & $\mathbf{S}$ & C6 & $\begin{array}{l}\text { Demonstrate with the help of } \\
\text { physical objects }\end{array}$ & 11 & 21.57 \\
\hline & & $\mathrm{C} 7$ & Draw pictures normatively & 2 & 3.92 \\
\hline & & $\mathrm{C} 8$ & $\begin{array}{l}\text { Strengthen students' thinking } \\
\text { training }\end{array}$ & 4 & 7.84 \\
\hline & & C9 & Adopt diverse teaching methods & 2 & 3.92 \\
\hline & & $\mathrm{C} 10$ & $\begin{array}{l}\text { Implement literacy through } \\
\text { geometric proof problems }\end{array}$ & 1 & 1.96 \\
\hline
\end{tabular}




\section{International Journal of Education Humanities and Social Science}

ISSN: 2582-0745

Vol. 5, No. 01; 2022

\begin{tabular}{|c|c|c|c|c|}
\hline & C11 & $\begin{array}{l}\text { Combine specific knowledge to } \\
\text { guide students }\end{array}$ & 6 & 11.76 \\
\hline & D1 & Simplify complex problems & 1 & 1.96 \\
\hline & D2 & Hands on & 7 & 13.73 \\
\hline & D3 & Observe frequently & 6 & 11.76 \\
\hline & D4 & Strengthen exercises & 6 & 11.76 \\
\hline \multirow[t]{5}{*}{$\begin{array}{l}\text { D } \\
\text { Students }\end{array}$} & D5 & Solve problems with models & 11 & 21.57 \\
\hline & D6 & Bold guesses & 2 & 3.92 \\
\hline & D7 & Develop good graphing habits & 2 & 3.92 \\
\hline & D8 & Master basic graphics & 3 & 5.88 \\
\hline & D9 & Understand the conceptual content & 1 & 1.96 \\
\hline
\end{tabular}

\subsection{Cognitive Comprehensiveness}

This research collated the strategies proposed by previous authors on the development of intuitive imagination literacy and finally summarized 46 points. The details are shown in Table 2.

Table 2 Coding of cultivation strategies proposed by previous authors

\begin{tabular}{llll}
\hline Primary & Secondary & Cod \\
Indicato & Content \\
rs & Indicators & e
\end{tabular}

\begin{tabular}{llll}
\hline E & E1 & $\begin{array}{l}\text { Balance the development of students' intuitive } \\
\text { imagination literacy between geographic regions }\end{array}$ \\
$\begin{array}{l}\text { Education } \\
\text { al } \\
\text { Authoritie } \\
\text { Teachin } \\
\text { g }\end{array}$ & E2 & $\begin{array}{l}\text { Reinforce the guidance of intuitive imagination } \\
\text { strategies and methods }\end{array}$ \\
& E3 & $\begin{array}{l}\text { Focus on the application of modern information } \\
\text { technology in developing students intuitive } \\
\text { imagination }\end{array}$ \\
Teachers & F2 & $\begin{array}{l}\text { Strengthen the links between disciplines } \\
\text { Carefully study the curriculum standards, integrate } \\
\text { teaching materials, and clarify teaching directions } \\
\text { and requirements }\end{array}$
\end{tabular}




\section{International Journal of Education Humanities and Social Science}

ISSN: 2582-0745

Vol. 5, No. 01; 2022

F3

F4

F5

F6 Create visual teaching situations

F7 Guide students to explore in various forms

F8 Teach students in a subtle way

F11

F12

G

Students G5
F9

F10

G1

G2

G3

G6

G7

G8

Coordinate the development of intuitive imagination and logical reasoning

Focus on the impact between intuitive imagination literacy and other core mathematical literacies

Focus on the needs and abilities of students at different levels

Enhance the development of students' awareness of visual imagination

Increase awareness of the application of graphics to solve problems

Form the ability to reason and argue from graphic language to textual language

Demonstrate, reflect and analyze spatial relationships with the help of nearby objects

G4 Enhance communication and imagination

Expand the space for autonomous operation and accumulate geometric intuitive experience

Seek creative breakthroughs in thinking for analogical learning

Develop geometric intuition with the help of visual models

Understand the relationship between vectors and geometry 


\section{International Journal of Education Humanities and Social Science}

ISSN: 2582-0745

Vol. 5, No. 01; 2022

\begin{tabular}{|c|c|c|c|}
\hline & & G9 & $\begin{array}{l}\text { Track the dynamics of shapes and explore } \\
\text { geometric patterns }\end{array}$ \\
\hline & & G10 & $\begin{array}{l}\text { Enhance editing operations to reflect the nature of } \\
\text { geometry }\end{array}$ \\
\hline & & $\mathrm{H} 1$ & $\begin{array}{l}\text { Strengthen practical teaching and focus on visual } \\
\text { demonstration teaching }\end{array}$ \\
\hline & & $\mathrm{H} 2$ & $\begin{array}{l}\text { Encourage students to communicate and express } \\
\text { themselves in mathematical language }\end{array}$ \\
\hline & & $\mathrm{H} 3$ & Use background materials reasonably \\
\hline & & $\mathrm{H} 4$ & $\begin{array}{l}\text { Make use of typical examples of mathematical } \\
\text { culture }\end{array}$ \\
\hline & & H5 & Improve students' interest in learning mathematics \\
\hline & & H6 & $\begin{array}{l}\text { Strengthen the teaching of parallel and } \\
\text { perpendicular relationships in space }\end{array}$ \\
\hline & $\mathbf{H}$ & $\mathrm{H} 7$ & Teach with modern information technology \\
\hline & Teachers & $\mathrm{H} 8$ & $\begin{array}{l}\text { Strengthen the teaching of number and shape } \\
\text { combination }\end{array}$ \\
\hline $\begin{array}{l}\text { Teachin } \\
\text { g }\end{array}$ & & H9 & $\begin{array}{l}\text { Choose visual tools to provide perceptual } \\
\text { understanding }\end{array}$ \\
\hline & & $\mathrm{H} 10$ & $\begin{array}{l}\text { Cultivate students' habit of reading, drawing and } \\
\text { using diagrams }\end{array}$ \\
\hline & & H11 & $\begin{array}{l}\text { Focus on the geometric meaning of the explanation, } \\
\text { highlighting the essence of the concept }\end{array}$ \\
\hline & & H12 & $\begin{array}{l}\text { Guide students to appreciate the mathematical ideas } \\
\text { and common mathematical techniques used in the } \\
\text { discovery of theorems }\end{array}$ \\
\hline & & H13 & $\begin{array}{l}\text { Develop students' ability to draw pictures } \\
\text { normatively }\end{array}$ \\
\hline & I & I1 & Focus on mathematical experimental manipulation \\
\hline & Students & $\mathrm{I} 2$ & $\begin{array}{l}\text { Learn to make connections between graphs and } \\
\text { shapes and graphs and quantities }\end{array}$ \\
\hline
\end{tabular}




\section{International Journal of Education Humanities and Social Science}

ISSN: 2582-0745

Vol. 5, No. 01; 2022

I3 Recognize simple geometry and accumulate

I4 Use models of space geometry to solve problems

I5 Learn to reflect spatial figures on a plane

I6

Learn to represent spatial figures with visual diagrams

Focus on variations of visual graphs to deepen understanding of the problem

I8

Use information software to recognize graphical relationships and develop spatial concepts

Matching preservice teachers' cognition of implementing intuitive imagination literacy with the content of previous studies reveals that current pre-service teachers realize 18 points of the content of previous studies, accounting for $39.13 \%$ of the total.

For the dimension of "general teaching", 25 points were proposed, of which 9 points were recognized by the pre-service teachers, accounting for $36.00 \%$. Among them, pre-service teachers recognized 5 points on the aspect of teachers, accounting for $41.67 \%$ of the total number of points in this section, and 4 points on the aspect of students, accounting for $40.00 \%$ of the total number of points in this section. However, they have no cognition on the aspect of educational authorities.

For the dimension of "classroom teaching", 21 points were proposed, of which 9 points were recognized by the pre-service teachers, accounting for $42.86 \%$. Among them, pre-service teachers recognized 6 points on the aspect of teachers, accounting for $46.15 \%$ of the total number of points in this section, and 3 points on the aspect of students, accounting for $37.50 \%$ of the total number of points in this section.

It can be seen that the current pre-service teachers' cognition of implementing intuitive imagination literacy is not comprehensive, whether from the overall perspective or two different dimensions of "general teaching" and "classroom teaching", and it is not half of the number of implementation suggestions put forward by previous authors. In addition, the subjects they recognize for implementation are limited to teachers and students and did not involve the other subjects of implementation proposed by the previous authors. The details are shown in Table 3.

Table 3. Statistics of cognitive comprehensiveness

\begin{tabular}{|c|c|c|c|c|c|c|c|}
\hline $\begin{array}{l}\text { Primary } \\
\text { Indicato } \\
\text { rs }\end{array}$ & $\begin{array}{l}\text { Secondar } \\
\mathbf{y} \\
\text { Indicators }\end{array}$ & $\begin{array}{l}\text { Recog } \\
\text { nizing } \\
\text { Points }\end{array}$ & $\begin{array}{l}\text { Total } \\
\text { Point } \\
\text { s }\end{array}$ & $\begin{array}{l}\text { Percen } \\
\text { tage }\end{array}$ & $\begin{array}{l}\text { Recognizi } \\
\text { ng Points }\end{array}$ & $\begin{array}{l}\text { Total } \\
\text { Points }\end{array}$ & $\begin{array}{l}\text { Percent } \\
\text { age }\end{array}$ \\
\hline
\end{tabular}




\section{International Journal of Education Humanities and Social Science}

ISSN: 2582-0745

Vol. 5, No. 01; 2022

\begin{tabular}{|c|c|c|c|c|c|c|c|}
\hline \multirow{3}{*}{$\begin{array}{l}\text { General } \\
\text { Teachin } \\
\text { g }\end{array}$} & $\begin{array}{l}\text { Education } \\
\text { al } \\
\text { Authoritie }\end{array}$ & 0 & 3 & 0.00 & \multirow{3}{*}{9} & \multirow{3}{*}{25} & \multirow{2}{*}{36.00} \\
\hline & \multicolumn{4}{|c|}{$\mathbf{s}$} & & & \\
\hline & Teachers & 5 & 12 & 41.67 & & & \\
\hline \multirow{3}{*}{$\begin{array}{l}\text { Classroo } \\
\text { m } \\
\text { Teachin } \\
\text { g }\end{array}$} & Students & 4 & 10 & 40.00 & & & \\
\hline & Teachers & 6 & 13 & 46.15 & \multirow[b]{2}{*}{9} & \multirow[b]{2}{*}{21} & \multirow[b]{2}{*}{42.86} \\
\hline & Students & 3 & 8 & 37.50 & & & \\
\hline \multicolumn{5}{|c|}{ Total Points } & 18 & 46 & 39.13 \\
\hline
\end{tabular}

\subsection{Cognitive Reasonableness}

The pre-service teachers' cognition of implementing intuitive imagination literacy was summarized as 37 points, of which 18 points were similar to the suggestions made by the previous authors, accounting for $48.65 \%$ of the total. For the dimension of "general teaching", the preservice teachers' statements were summarized as 17 points, of which 9 points were similar to the previous suggestions, accounting for $52.94 \%$; for the dimension of "classroom teaching", the preservice teachers' statements were summarized as 20 points, of which 9 points were similar to the previous suggestions, accounting for $45.00 \%$.

In terms of specific contents, the contents of "use visual tools such as graphics", "demonstrate with the help of modern information technology such as multimedia" and others, which were recognized by the pre-service teachers, were more consistent with the implementation suggestions made by the previous authors. However, more than half of the contents they recognized, such as "enhance the focus on core literacy" and "improve the ability to combine numbers and shapes", are not reflected in the implementation suggestions of the previous authors.

It can be seen that the pre-service high school mathematics teachers' cognition of implementing intuitive imagination literacy was not very reasonable. Less than half of the implementation measures they proposed could match the implementation recommendations made by the previous authors; at the same time, some of the implementation measures that pre-service teachers could realize were unreasonable compared with the previous recommendations and still existed in a certain one-sided way. The details are shown in Table 4 and Table 5.

Table 4. Statistics of cognitive reasonableness

\begin{tabular}{llllllll}
\hline Primary & & Recogni & Total & Percenta & $\begin{array}{l}\text { Recogni } \\
\text { zing }\end{array}$ & Total & Percenta \\
Indicato & Seconda & zing & Point & ger & ge \\
rs & ry & Points & s & & Points & & \\
\hline
\end{tabular}


ISSN: 2582-0745

Vol. 5, No. 01; 2022

\begin{tabular}{llllllll}
\hline \multicolumn{2}{c}{$\begin{array}{l}\text { Indicato } \\
\text { rs }\end{array}$} & & & & & \\
\hline $\begin{array}{l}\text { General } \\
\text { Teaching }\end{array}$ & Teachers & 5 & 10 & 50.00 & & \\
Students & 4 & 7 & 57.14 & & & 52.94 \\
Classroo & Teachers & 6 & 11 & 54.55 & & & \\
$\begin{array}{l}\text { m } \\
\text { Teaching }\end{array}$ & Students & 3 & 9 & 33.33 & & 20 & 45.00 \\
Total Points & & & & 18 & 37 & 48.65 \\
\hline
\end{tabular}

Table 5. Statistics of matching situation

\begin{tabular}{llllll}
\hline Primary & Seconda & & & Nu & Perce \\
Indicato & ry & Cod & Content & mbe & $\begin{array}{l}\text { Perce } \\
\text { ntage }\end{array}$ \\
rs & rs & & & r
\end{tabular}

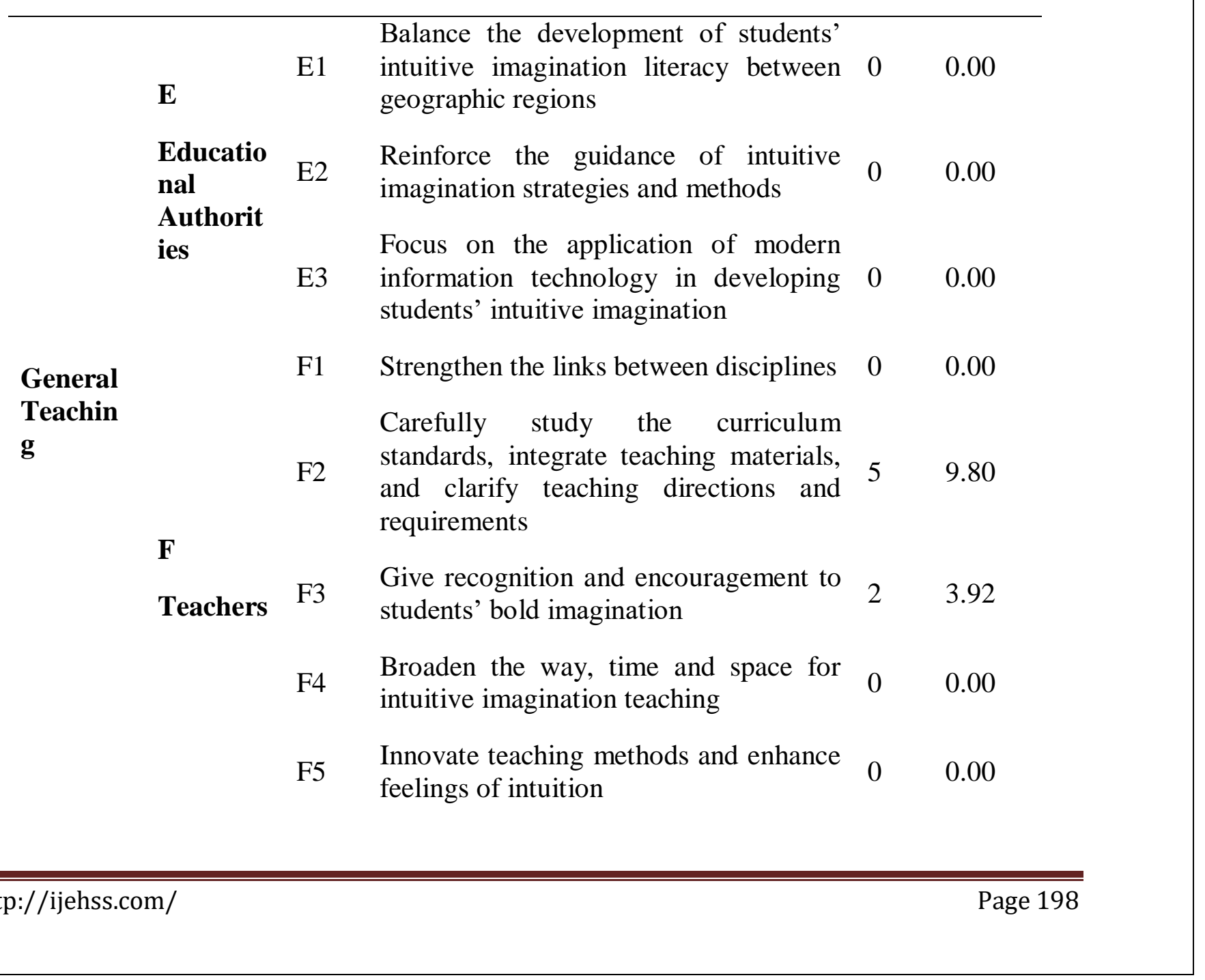




\section{International Journal of Education Humanities and Social Science}

ISSN: 2582-0745

Vol. 5, No. 01; 2022

\begin{tabular}{|c|c|c|c|}
\hline F6 & Create visual teaching situations & 8 & 15.65 \\
\hline F7 & $\begin{array}{l}\text { Guide students to explore in various } \\
\text { forms }\end{array}$ & 0 & 0.00 \\
\hline F8 & Teach students in a subtle way & 1 & 1.96 \\
\hline F9 & $\begin{array}{l}\text { Coordinate the development of intuitive } \\
\text { imagination and logical reasoning }\end{array}$ & 0 & \\
\hline
\end{tabular}

Focus on the impact between intuitive

F10 imagination literacy and other core $0 \quad 0.00$ mathematical literacies

F11 Focus on the needs and abilities of $0 \quad 0.00$ students at different levels

F12 Enhance the development of students' awareness of visual imagination

Increase awareness of the application of graphics to solve problems

Form the ability to reason and argue

G2 from graphic language to textual $0 \quad 0.00$ language

Demonstrate, reflect and analyze spatial

G3 relationships with the help of nearby $3 \quad 5.88$ objects

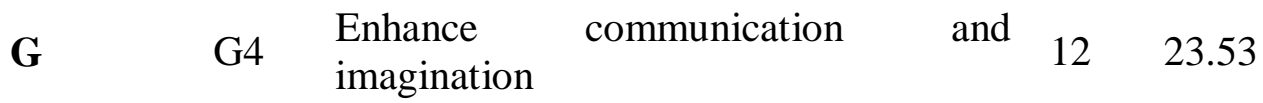

Students

Expand the space for autonomous

G5 operation and accumulate geometric $11 \quad 21.57$ intuitive experience

G6

Seek creative breakthroughs in thinking for analogical learning

G7

Develop geometric intuition with the help of visual models

G8 Understand the rela 0.00 


\section{International Journal of Education Humanities and Social Science}

ISSN: 2582-0745

Vol. 5, No. 01; 2022

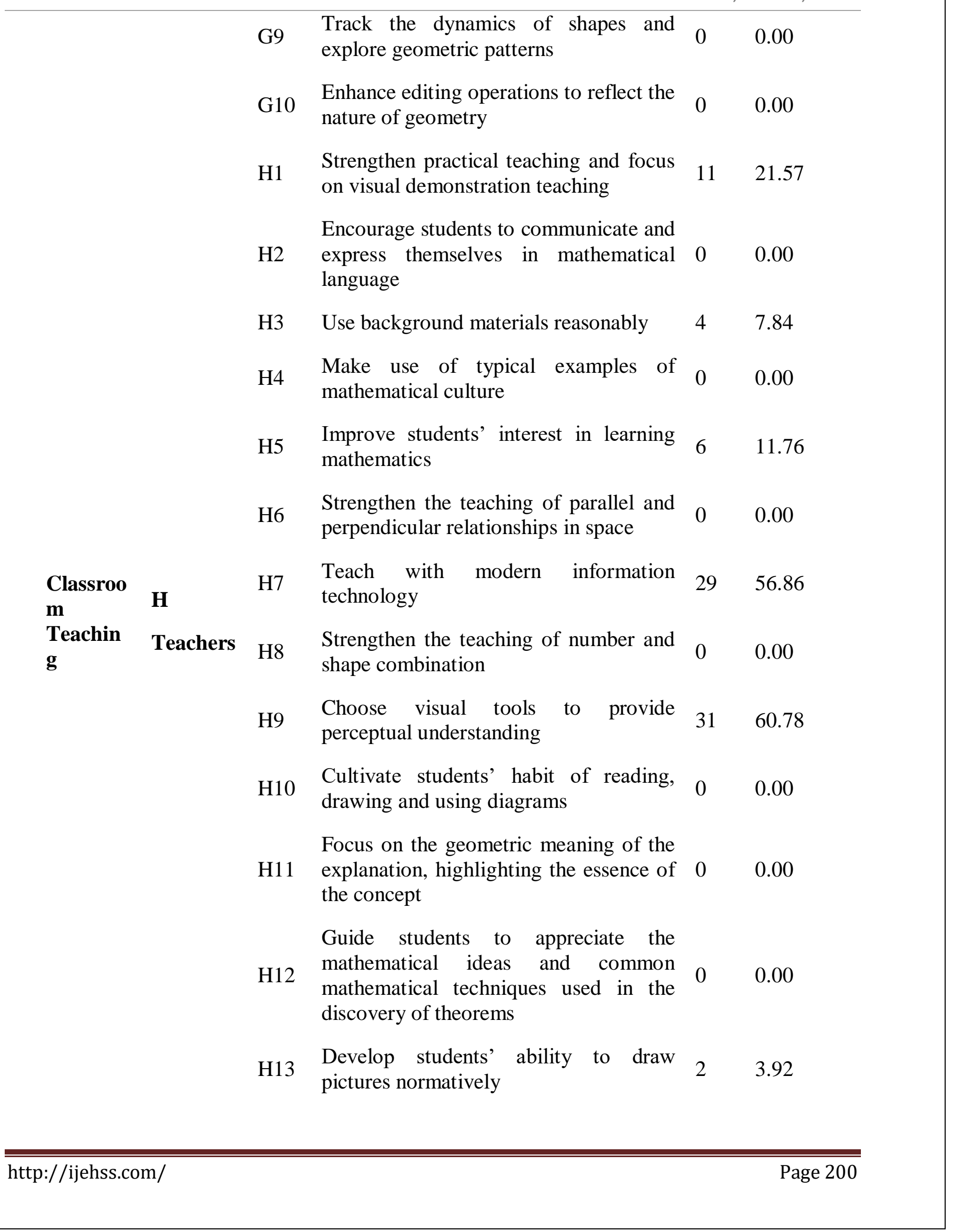




\section{International Journal of Education Humanities and Social Science}

ISSN: 2582-0745

Vol. 5, No. 01; 2022
I1
Focus on mathematical experimental
manipulation
$7 \quad 13.73$
Learn to make connections between
I2 graphs and shapes and graphs and $0 \quad 0.00$ quantities
Recognize simple geometry and
I3 accumulate representations of spatial $3 \quad 5.88$ figures
$\begin{array}{lllll}\text { I } & \text { I4 } & \begin{array}{l}\text { Use models of space geometry to solve } \\ \text { problems }\end{array} & 11 & 21.57\end{array}$
I5 Learn to reflect spatial figures on a plane $\begin{array}{lll}0 & 0.00\end{array}$
Learn to represent spatial figures with visual diagrams
$0 \quad 0.00$
Focus on variations of visual graphs to
deepen understanding of the problem
$0 \quad 0.00$
I8
Use information software to recognize
graphical relationships and develop $0 \quad 0.00$ spatial concepts

\section{DISCUSSION}

\subsection{Cognitive Focus}

According to the above data analysis, it can be seen that for implementing intuitive imagination literacy, current pre-service high school mathematics teachers have recognized two implementation subjects, teachers and students, from different dimensions. For the "general teaching" dimension, pre-service teachers pay more attention to the important role of students as learning agents in this dimension. They realized that to better implement intuitive imagination literacy, students need to have the ability to combine numbers and shapes, spatial imagination, and hands-on practice. Meanwhile, teachers need to have the awareness of developing students' intuitive imagination and have certain teaching skills. For the "classroom teaching" dimension, the pre-service teachers pay more attention to the important role of teachers in classroom teaching. They realize that teachers need to relate to real-life situations in the classroom teaching process and teach with the help of modern information technology and visual tools to stimulate students' interest in learning, and they also emphasize students' direct participation in the learning process. From this we can see that current pre-service high school mathematics teachers can realize the importance of teachers and students for implementing intuitive imagination literacy; students should experience the whole process of intuitive imagination and hands-on practice, while the teacher should play a leading role in the classroom and adopt an effective way of teaching. 


\subsection{Cognitive Comprehensiveness}

According to the above data analysis, it can be seen that the current pre-service teachers' cognition of implementing intuitive imagination literacy is not comprehensive, whether from the overall perspective or two different dimensions of "general teaching" and "classroom teaching", and it is not half of the number of implementation suggestions put forward by previous authors. In addition, the subjects they recognize for implementation are limited to teachers and students and did not involve the other subjects of implementation proposed by the previous authors. From this, we can see that current pre-service high school mathematics teachers do not have a comprehensive cognition of implementing intuitive imagination literacy. This conclusion coincides with the findings of previous studies. Chang believes that at the present stage, front-line teachers' cognition of intuitive imagination often stays at a certain level, such as "shape" supplemented by "number", which neglects the hierarchy of developing intuitive imagination literacy (Chang, 2020).

\subsection{Cognitive Reasonableness}

According to the above data analysis, it can be seen that the pre-service high school mathematics teachers' cognition of implementing intuitive imagination literacy was not very reasonable. Less than half of the implementation measures they proposed could match the implementation recommendations made by the previous authors; at the same time, some of the implementation measures that pre-service teachers could realize were unreasonable compared with the previous recommendations and still existed in a certain one-sided way. From this, we can see that preservice high school mathematics teachers do not have a very reasonable cognition for implementing intuitive imagination literacy. Similar findings were found in previous studies. Du found that teachers used many methods to develop students' intuitive imagination literacy in classroom teaching, but they applied them in a non-specific and indiscriminate way, while the effectiveness of some of their suggestions and strategies to develop students' intuitive imagination literacy in mathematics is to be tested (Du, 2019).

\section{CONCLUSION AND RECOMMENDATIONS}

It has been shown that teachers' cognition for implementing intuitive imagination literacy directly affects the implementation effect of intuitive imagination literacy. The current implementation effect of intuitive imagination literacy in the high school mathematics classroom is not good, so is it that teachers' cognition for implementing intuitive imagination literacy is not comprehensive? Is it not reasonable? In this study, we investigated pre-service high school mathematics teachers' cognitive situation of implementing intuitive imagination literacy. Through investigation and analysis, it can be seen that pre-service high school mathematics teachers do not have a comprehensive cognition for implementing intuitive imagination literacy. Their cognition, both as a whole and in different dimensions, does not reach half of the number of implementation recommendations made by the previous authors, and the subjects they realize for implementation are limited to both teachers and students. In addition, pre-service high school mathematics teachers do not have a very reasonable cognition. Some of their ideas lack feasibility or effectiveness and exist a certain one-sidedness, which needs to be further explored and considered. 


\section{International Journal of Education Humanities and Social Science}

ISSN: 2582-0745

Vol. 5, No. 01; 2022

According to the above conclusions, it is recommended: 1 . The teachers and experts who educate pre-service high school mathematics teachers should pay more attention to intuitive imagination literacy, strengthen pre-service teachers' training in this area, and provide them with more opportunities to practice teaching; 2. Pre-service high school mathematics teachers themselves should take the initiative to study and research, seize the opportunities of teaching exercises, focus on combining theory and practice, and constantly reflect, adjust and improve.

The subjects of this study were 51 masters of education students in the same grade at the same institution, so the limitation of this research is that the sample size was small and did not involve other types of pre-service high school mathematics teacher groups. Therefore, in order to find more detailed and comprehensive results, it is necessary to expand the scope of the research sample and adopt a variety of research methods to conduct a more in-depth study.

\section{Founding}

This research was supported by Shandong Provincial Education Department (Grant number:SDYJG21023).

\section{Competing Interests}

The authors declare that they have no competing interests.

\section{REFERENCES}

Chang, G. L. (2020). The triple realm of permeating intuitive imagination literacy in mathematics teaching. Teaching and Management, 37(31), 62-64.

Chen, M. (2018). Survey on the current situation of intuitive imagination core literacy of high school students, Master's Thesis. Guiyang: Guizhou Normal University.

Du, J. (2019). Research on factors influencing high school students' intuitive imagination literacy, Master's Thesis. Jinan: Shandong Normal University.

$\mathrm{Gu}, \mathrm{X}$., and Wang, C. (2020). Exploration of strategies for developing intuitive imagination literacy based on mathematical problem solving. Contemporary Educational Practice and Teaching Research, 7(02), 84-85.

Jin, Y. M. (2016). Discussing visual imagination ability by examples. New Curriculum (Volume 2 of 2), 12(11), 202.

Li, C. G. (2019). Research on the 2019 Advanced Placement Mathematics Test from an Intuitive Imagination Perspective. Basic Education Curriculum, 15(16), 25-33.

Li, X. T. (2021). Research on the development of mathematical intuitive imagination literacy of high school students, Master's Thesis. Chongqing: Southwest University.

Lin, P. S. (2021). The impact of GeoGebra software on the development of intuitive imagination literacy in mathematics classrooms. Knowledge Window (Teacher's Edition), 13(07), 68-69.

Liu, J., Liu, P. K., and Guo, Y. F. (2020). Research on mathematics entrance examination questions based on the composition and level classification of intuitive imagination literacy. Bulletin des Sciences Mathematics, 59(03), 35-40.

Ministry of Education of the People's Republic of China. (2018). General High School Mathematics Curriculum Standards (2017 Edition). Beijing: People's Education Press.

Shen, J. X., and Wang, F. P. (2017). From a perspective of PME seeing intuitive imagination literacy and its development. Educational Research and Review (Secondary Education Teaching), 9(04), 11-15. 


\section{International Journal of Education Humanities and Social Science}

ISSN: 2582-0745

Vol. 5, No. 01; 2022

Tao, W. (2021). Research on the correlation between logical reasoning ability and intuitive imagination ability of sophomore students, Master's Thesis. Nanjing: Nanjing Normal University.

Weng, Y. P. (2017). Research on the assessment of mathematical intuitive imagination literacy of high school students, Master's Thesis. Fuzhou: Fujian Normal University.

Yang, X. Y. (2012). Investigation of mathematical intuitive ability of high school students, Master's Thesis. Yangzhou: Yangzhou University.

Yin, D. Y. (2017). Research on the level of mathematical intuitive imagination of high school students, Master's Thesis. Suzhou: Soochow University.

Yu, P. (2017). A framework for assessing mathematical core literacy. Journal of Mathematics Education, 26(02), 19-23+59.

Zhang, D. Q., and Pei, Y. (2020). Research on the intuitive imagination literacy of elementary and middle school students: a review and outlook. Journal of Beijing Institute of Education, 34(05), 24-32.

Zhang, J. X., and Han, H. J. (2017). The way to develop the intuitive imagination literacy of senior students. Secondary School Mathematics, 39(15), 31-34.

Zheng, X. J., Chen, Q. H., and Ke, Y. H. (2021). Construction of a model for assessing the mathematical intuitive imagination literacy of high school students. Educational Research and Experimentation, 40(03), 71-78.

Zheng, X. J., Chen, Q. H., Wang, C. P., and Lin, J. R. (2020). Research on the measurement and evaluation of intuitive imagination literacy of high school students. Journal of Mathematics Education, 29(04), 7-12.

Zhu, L. M. (2020). Construction of a framework for assessing the mathematical core literacy of high school students. Chinese Journal of Education, 41(07), 78-83. 